Malahayati International Journal of Nursing and Health Science, Volume 02, No.2, September 2019: 80-85

\title{
Effects of health training in knowledge and surgical wound management
}

\author{
Eka Yudha Chrisanto ${ }^{1}$, Nur Afni²
}

1Diploma III in Nursing-Malahayati University, Bandar Lampung, Indonesia. Email: yudhachrisanto88@gmail.com 2Dr. A. Dadi. Tjokrodipo General Hospital-Bandar Lampung, Indonesia. Email: nurafni@gmail.com

\begin{abstract}
Background: The surgery in Indonesia ranks 11th out of 50 treatments for disease patterns in hospitals in Indonesia, which is an estimated $32 \%$ of them were laparotomy. The number of abdominal surgical cases in Lampung Province in 2017 was (28.95\%) and increased in 2018 by (32.45\%).

Purpose: Know the effect of health training in knowledge and surgical wound management.

Methods: This type of study was quantitative, with the Pre-Experiment design and the design one group pre test - post test. The populations were all of postoperative patients and samples of 34 people with a total sampling technique. Data collection uses questionnaire sheets and the statistical test used dependent t-test.

Results: The average knowledge about postoperative wound care before being given health training of 14.18 and a standard deviation of 1.749 . The average knowledge about postoperative wound care after being given health training of 17.06 and a standard deviation of 3.142 , with $p$-value $=(0,000<0,05)$.

Conclusion: There was the effect of health training in knowledge and surgical wound management. Health workers are expected to be able to apply the provision of health training to postoperative patients to improve patient knowledge in subsequent care and be used as a reference for making policies regarding the provision of health training to postoperative patients.
\end{abstract}

\section{Keywords: Knowledge; Health training; Surgical wound management}

\section{INTRODUCTION}

Surgery performs an invasive treatment by opening or displaying the part of the body to be treated. This body opening is generally carried out by making an incision after the part to be treated is displayed and corrective actions will be taken which will end with closure by suturing the wound (Kozier, \& Erb, 2009; Sjamsuhidayat, 2012; Rustianawati, Karyati, \& Himawan, 2013). Broadly speaking, surgery can be divided into two, namely minor surgery and major surgery. In major surgery, anesthesia is administered which consists of two types of anesthesia, regional anesthesia and general anesthesia. Major surgery is a surgical procedure that involves the body's organs widely and has a high level of risk to the survival of the client (Potter, \& Perry, 2006; Maryunani, 2014).

The number of patients undergoing surgery achieves a very significant increase from year to year. In 2011 there were 140 million patients in all hospitals in the world, while in 2012 the data had increased by 148 million people (Rahmayati, Silaban, \& Fatonah, 2018).

Surgical action in Indonesia ranks 11 th out of the first 50 handling of disease patterns in hospitals throughout Indonesia, an estimated $32 \%$ of which are laparoscopic surgery (Ministry of Health of the Republic of Indonesia, 2017). The number of abdominal surgery cases in Lampung Province in 2017 was $(28.95 \%)$ and increased in 2018 by $(32.45 \%)$ (Lampung Provincial Health Office, 2018).

The main barriers to the wound healing process are necrotic tissue, germ growth or infection, and excessive exudate. Factors that can support postoperative wound healing and affect the risk of surgical site infection are local blood flow, the presence or absence of edema, burners and builders, cleanliness of the wound, the size of the wound, dryness or absence of the wound (Said, Taslim, \& Bahar, 2013; Maghfuri, 2015). healing Wound Through the process of replacement and repair of damaged tissue functions. Wound healing 
phases namely the inflammatory phase lasts for 1-4 days, the proliferative phase lasts 5-20 days, and the maturation phase lasts 21 days to a month or even years (Purwoastuti, \& Walyani, 2015).

The unpreparedness of patients facing repatriation can also occur because patients are discharged too quickly so this also risks the occurrence of post-surgical complications after being at home, and also due to unplanned repatriation which can result in re-hospitalization (Kusumayanti, 2014). The majority of patients who receive information about pain and wound management, activity, nutrition, and complications in general feel that they do not experience feelings of worry that will make them make irregular visits to health facilities after discharge. Whereas patients who are not informed about pain and wound management, experience concerns that force them to make non-routine visits to a health facility after discharge, therefore patients need to be prepared to face repatriation (Rohana, Kustriyani, \& Personal, 2015).

In 2018, there were 824 general surgical patients, including those who had appendicitis surgery which $47.25 \%$,surgery laparotomy reached as much as $32.30 \%$ and hernia as much as $12.45 \%$ as much as $7.12 \%$. The results of the pre survey in December 2018 by observing 10 postoperative patients whose controls on days 1-5 were known in postoperative wounds, there were $5(50 \%)$ experiencing abnormal wound healing, ie wound condition that was not in accordance with the phase, time and wound healing events. When interviewed there were $80 \%$ of them had a level of knowledge about post-operative wound care is not good so that the potential for infection in the wound. If this is allowed then the impact that occurs is the wound healing process in postoperative patients will last long (RSUD Dr. A. Dadi. Tjokrodipo Kota Bandar Lampung, 2018).

\section{RESEARCH METHODS}

Quantitative research type, with a research design Pre Experimental and approach one group pretest - posttest design. This research has passed the ethical feasibility of the Health Research Ethics Commission (HREC) of Malahayati University and was carried out at Tjokrodipo general hospital Bandar Lampung, from June to July 2019. The population of all postoperative patients and samples was 34 respondents with total sampling technique. Data analysis used dependent $t$-test to test the mean / average difference of knowledge before and after having a health training.

The data collected by using a questionnaire sheet to measure knowledge variables with consisting of 20 questions with a score range of 0 20 , and conducted before (pre-test) and after (posttest). The health training was done in postoperative patients with an average time of 30 minutes, at the surgical treatment ward and by reseaceher to each patient.

Eka Yudha Chrisanto' Diploma IIl in Nursing-Malahayati University, Bandar Lampung, Indonesia. Email: yudhachrisanto88@gmail.com

Nur Afni ${ }^{2}$ Dr. A. Dadi. Tjokrodipo General Hospital-Bandar Lampung, Indonesia. Email: nurafni@gmail.com 
Malahayati International Journal of Nursing and Health Science, Volume 02, No.2, September 2019: 80-85

Effects of health training in knowledge and surgical wound management

\section{RESEARCH RESULTS}

Table 1. Frequency Distribution Characteristics of Respondents

\begin{tabular}{lcc}
\hline Characteristics of Respondents & $\begin{array}{c}\text { Frequency } \\
\text { (f) }\end{array}$ & $\begin{array}{c}\mathbf{N}=\mathbf{3 4} \\
\text { Percentage } \\
(\%)\end{array}$ \\
\hline Education Levels & & \\
Primary school & 4 & 11,76 \\
Secondary school & 10 & 29,42 \\
High school & 12 & 35,29 \\
University & 8 & 23,53 \\
& & \\
Job Title & & \\
Government Employees & 8 & 23,53 \\
Entrepreneur & 6 & 17,54 \\
Labor & 13 & 38,24 \\
Unemployed & 7 & 20,59 \\
\hline
\end{tabular}

Based on Table 1. it can be seen that the educational characteristics of post-operative patients, partly The large is SMA as many as 12 respondents $(35.29 \%)$. Most of the jobs are laborers as many as 13 respondents $38.24 \%)$.

Table 2. The Average of Knowledge Before and After Health Training

\begin{tabular}{lcccc}
\hline Group & Mean & SD & SE & Min-max \\
\hline Before health training & 14,18 & 1,749 & 0,300 & $11-18$ \\
After health training & 17,06 & 3,142 & 0,539 & $12-23$ \\
\hline
\end{tabular}

The results of the study from Table 2. show that the average average knowledge about postoperative wound care before being given health training had an average value of 14.18 and a standard deviation of 1.749. A minimum value of 11 and a maximum of 18 . Whereas, the results of the study showed that the average knowledge about post-operative wound care after being given health training in the contents of my plate had an average value of 17.06 and a standard deviation of 3.142 and. Minimum value of 12 and a maximum 23.

Table 3. Effect of Health Training on Knowledge of Postoperative Wound Care $\mathrm{N}=34$

\begin{tabular}{lccccc}
\hline Group & Mean & SD & $\mathbf{t}$ & $\mathbf{p}$-value & $\begin{array}{c}\text { Perbedaan rerata } \\
\text { Cl 95\% }\end{array}$ \\
\hline $\begin{array}{l}\text { Before health } \\
\text { training }\end{array}$ & 14,18 & 1,966 & 8,549 & $\mathbf{0 , 0 0 0}$ & $\mathbf{2 , 8 8 2}$ \\
$\begin{array}{l}\text { After health } \\
\text { training }\end{array}$ & 17,06 & & & & $\mathbf{3 , 5 6 8 - 2 , 1 9 6}$ \\
\hline
\end{tabular}

The results of the analysis from table 3 above can be known differences in the average knowledge of wound care in postoperative patients before and after health training was given at 2.882 and a standard deviation of

Eka Yudha Chrisanto' Diploma 111 in Nursing-Malahayati University, Bandar Lampung, Indonesia. Email: yudhachrisanto88@gmail.com

Nur Afni ${ }^{2}$ Dr. A. Dadi. Tjokrodipo General Hospital-Bandar Lampung, Indonesia. Email: nurafni@gmail.com 
Malahayati International Journal of Nursing and Health Science, Volume 02, No.2, September 2019: 80-85

Effects of health training in knowledge and surgical wound management

1.966. The test results obtained $p$ value $=(0,000<0.05)$ so that there is an influence of health training on knowledge about post-operative wound care, obtained a OR value of 15.400 .

\section{DISCUSSION}

Based on the results of data processing, it can be seen that the average knowledge about postoperative wound care before being given health training has an average value of 14.18 and a standard deviation of 1.749 . A minimum value of 11 and a maximum of 18 . The average knowledge after being given health training in the content of my plate content has an average value of 18.06 and a standard deviation of 2,400 and. Minimum value of 12 and a maximum of 23 .

Human behavior is essentially an activity of humans themselves. Therefore, human behavior has a very broad range that includes walking, talking, reacting, dressing and so on. Even internal activities (internal activity) such as thinking, perception and emotions which are human behavior. Knowledge occurs after someone senses a certain object. Without knowledge a person has no basis for making decisions and determining actions against the problems faced (Notoatmodjo, 2014).

Knowledge possessed by a person can be influenced by information factors obtained from both formal and non-formal education can have an immediate impact (immediate impact) so as to produce a change or increase in knowledge (Riyanto, 2013).

Health training where a dynamic process of behavior change occurs, the change is not just a process of transferring material / theory from one person to another and not a set of procedures, but the change occurs because of awareness from within the individual, group or community itself. The main purpose of health training is for people to be able to determine their own problems and needs, understand what they can do about the problem, with the resources available to them plus external support and decide on appropriate activities to improve the healthy living standards and welfare of the community (Mubarak, \& Chayatin, 2014).

In line with previous research, the level of knowledge obtained before the provision of health training was a mean of 16.33 , a median of 17.00 , a level of knowledge after the provision of health training was a mean of 15.90 median of 16.00 (Rohana, Kustriyani, \& Personal, 2015).

The results of this study can be known that most of the level of knowledge of patients after health training is higher than the level of knowledge of respondents before being given health training. This happens because health training is given to post-operative patients which includes knowledge about surgical wound care, coping with pain from surgery wounds, things that need to be avoided by postoperative patients, postoperative patient activities, postoperative patient nutrition, use of drugs by postoperative patients. Based on this the researcher believes that the respondents' knowledge about post-operative wound care is due to their lack of sensing of information about postoperative wound care that impacts the respondent's knowledge in health behavior. For this reason, respondents are advised to be able to utilize knowledge about postoperative wound care to speed healing.

\section{Effect of Health Training on Knowledge of Wound Care}

Differences in average knowledge of wound care in postoperative patients before and after health training was given at 2.882, and standard deviation of 1.966 . The test results obtained $p$ value $=(0,000<0.05)$ so that there is an influence of health training on knowledge about postoperative wound care.

Health training in the application or applied in the health field. Operationally health training to provide and or improve knowledge, attitudes, and practices of individuals, groups or communities in maintaining and improving their own health. Health training methods by applying training in the health field, operationally all activities to provide or enhance knowledge (Notoatmojo, 2014).

Knowledge occurs after people sensing a certain object. Sensing that occurs through the five human senses namely the sense of sight, hearing, smell, taste and touch. Most of human sensing is obtained through the eyes and ears. Cognitive knowledge is a very important domain in shaping

Eka Yudha Chrisanto' Diploma III in Nursing-Malahayati University, Bandar Lampung, Indonesia.

Email: yudhachrisanto88@gmail.com

Nur Afni ${ }^{2}$ Dr. A. Dadi. Tjokrodipo General Hospital-Bandar Lampung, Indonesia. Email: nurafni@gmail.com 
Malahayati International Journal of Nursing and Health Science, Volume 02, No.2, September 2019: 80-85

Effects of health training in knowledge and surgical wound management

one's actions (overt behavior) (Notoatmodjo, 2014).

Nursing interventions are needed because of the inability to perform self-care as a result of limitations. One form of nursing intervention that can be done with health training. Health training is essentially an activity or effort to deliver health messages to the community, groups or individuals. Hope with this message the community, family or individual can gain knowledge about better health (Notoatmodjo, 2012).

This is also in line with the opinion of other researchers that patients who receive information about pain and wound management, activity, nutrition, and complications in general feel that they do not experience feelings of worry which will make them make irregular visits to health facilities after discharge. Whereas patients who are not informed about pain and wound management, experience concerns that force them to make nonroutine visits to a health facility after discharge, therefore patients need to be prepared to face repatriation (Rohana, Kustriyani, \& Personal, 2015).

This study is in line with previous studies using the Wilcoxon statistical test obtained $p$-value = $0,000<$ (a) $0.05 \%$. There is an influence of wound care health education on the level of knowledge and attitude of first aid to students (Lasut, Mulyadi, \& Killing, 2018).

Other studies using questionnaires and analyzed using the test Wilcoxon. Statistical test results showed that there was an effect of health training on the level of patient knowledge about postoperative care with $p=0.009$ and $a=0.05$ (Rohana, Kustriyani, \& Personal, 2015).

According to researchers, health training attempts to increase knowledge and awareness, in addition to attitudes and behavior. Increased knowledge after being given health training occurs because of the treatment given to respondents in the form of media health training contents of my plate healthy community movement. After getting a stimulus in the form of health training, in a person the process of receiving knowledge occurs where the person realizes in the sense of knowing in advance the stimulus (object). In this case the respondent is aware and aware of the existence of health training on post-operative wound care which contains material on understanding, how to treat wounds, factors that influence wound healing and wound healing phase. After that interest (feeling interested), that person starts to be attracted to the stimulus or object. Here the attitude of the subject has begun to arise. Respondents felt interested in attending counseling and were enthusiastic in listening to the material presented in health training.

\section{CONCLUSION}

majority of patients with high school education were 12 respondents (35.29\%). Most of the occupations are laborers as many as 13 respondents $38.24 \%$ ). The average knowledge about postoperative wound care before being given health training was 14.18 and the standard deviation was 1.749 , while the average after being given health training was 17.06 and the standard deviation was 3.142. There is an influence of health training on knowledge of postoperative wound care with $p=(0,000<0.05)$

\section{RECOMMENDATION}

It is expected that health workers can apply the provision of health training to postoperative patients to increase patient knowledge in subsequent care and serve as a reference for making policies regarding the provision health training for postoperative patients.

It is recommended for respondents to be able to utilize the knowledge about postoperative wound care that has been given by nurses, to be able to be carried out when the patient is at home in order to accelerate the healing of surgical wounds, as well as to maintain the cleanliness of the wound so as not to get infected.

\section{REFERENCES}

Dinas Kesehatan Provinsi Lampung. (2018). Profil Dinas Kesehatan Provinsi Lampung. Lampung: Dinkes Provinsi Lampung.

Eka Yudha Chrisanto' Diploma IIl in Nursing-Malahayati University, Bandar Lampung, Indonesia. Email: yudhachrisanto88@gmail.com

Nur Afni ${ }^{2}$ Dr. A. Dadi. Tjokrodipo General Hospital-Bandar Lampung, Indonesia. Email: nurafni@gmail.com 
Malahayati International Journal of Nursing and Health Science, Volume 02, No.2, September 2019: 80-85

Effects of health training in knowledge and surgical wound management

Kementerian Kesehatan Republik Indonesia. (2017). Data dan informasi profil kesehatan Indonesia 2016. Jakarta: Pusat Data dan Informasi Kementerian Kesehatan RI.

Kozier, B., \& Erb, G. (2009). Buku ajar praktik keperawatan klinis. Jakarta: EGC.

Kusumayanti, P. D. (2014). Faktor-faktor yang berpengaruh terhadap lamanya perawatan pada pasien pasca operasi laparatomi. Coping (Community of Publishing in Nursing), 3(1).

Lasut, N. G. C., Mulyadi, N., \& Killing, M. (2018). Pengaruh pendidikan kesehatan perawatan luka akibat kecelakaan terhadap tingkat pengetahuan dan sikap pertolongan pertama pada siswa kelas $\mathrm{x}$ di SMK Negeri 6 Manado. Jurnal Keperawatan,6(1).

Maghfuri, A. (2015). Keterampilan Dasar Perawatan Luka Bagi Pemula. Jakarta: TIM.

Maryunani. A. (2014). Asuhan Keperawatan Peri Operatif-Pre Operasi (Menjelang Pembedahan). Jakarta: Trans Info Media.

Mubarak, W. I., \& Chayatin, N. (2014). IImu kesehatan masyarakat: teori dan aplikasi. Jakarta: Salemba Medika.

Notoatmodjo, S. (2012). Pendidikan dan perilaku kesehatan. Jakarta: Rineka Cipta.

Notoatmodjo, S. (2014). IImu Perilaku. Jakarta: Penerbit PT. Rineka Cipta.

Notoatmodjo, S. (2014). Promosi Kesehatan. Jakarta: Penerbit PT. Rineka Cipta.
Potter, P. A., \& Perry, A. (2006). Buku Ajar Fundamental Keperawatan, Volume 2, Edisi 4. Penerbit Buku Kedokteran EGC, Jakarta.

Purwoastuti, E., \& Walyani, E. S. (2015). IImu Obstetri dan Ginekologi Sosial Bagi Kebidanan. Yogyakarta: PT. Pustaka Baru.

Rahmayati, E., Silaban, R. N., \& Fatonah, S. (2018). Pengaruh Dukungan Spritual terhadap Tingkat Kecemasan pada Pasien PreOperasi. Jurnal Kesehatan, 9(1), 138-142.

Riyanto, A. (2013). Kapita selekta kuesioner pengetahuan dan sikap dalam penelitian kesehatan. Jakarta: Salemba Medika.

Rohana, N., Kustriyani, M., \& Pribadi, L. S. (2012). Pengaruh pendidikan kesehatan terhadap tingkat pengetahuan pasien tentang perawatan pasca operasi di Ruang Amarilis I RSUD Tugurejo Semarang.

Rumah Sakit Umum Daerah Dr. A. Dadi. Tjokrodipo Kota Bandar Lampung. (2018). Data rekam medik. Bandar Lampung: RSUD Dr. A. Dadi. Tjokrodipo Kota Bandar Lampung.

Rustianawati, Y., Karyati, S., \& Himawan, R. (2013). Efektivitas ambulasi dini terhadap penurunan intensitas nyeri pada pasien post operasi laparatomi di RSUD Kudus. Jurnal IImu Keperawatan dan Kebidanan, 4(2).

Said, S., Taslim, N. A., \& Bahar, B. (2013). Gizi dan Penyembuhan Luka. Jakarta: EGC.

Sjamsuhidayat. (2012). Buku Ajar IImu Bedah. Edisi 3. Jakarta : EGC.

Eka Yudha Chrisanto' Diploma 111 in Nursing-Malahayati University, Bandar Lampung, Indonesia. Email: yudhachrisanto88@gmail.com

Nur Afni ${ }^{2}$ Dr. A. Dadi. Tjokrodipo General Hospital-Bandar Lampung, Indonesia. Email: nurafni@gmail.com 